\title{
Pengembangan Bahan Ajar Menyimak Berbasis Multimedia Interaktif pada Pelajaran Tematik dengan Tema "Indahnya Kebersamaan" untuk Siswa Kelas IV Sekolah Dasar
}

\author{
Development of Listening Teaching Materials Based on Interactive Multimedia in \\ Thematic Lessons with the Theme of "The Beauty of Togetherness" for Class IV \\ Elementary School Students
}

\author{
Linda Apriati ${ }^{1, *}$, Widyatmike Gede Mulawarman ${ }^{2}$, dan Mohammad Ilyas ${ }^{3}$ \\ ${ }^{1}$ Magister Pendidikan Bahasa dan Sastra Indonesia, \\ FKIP Universitas Mulawarman \\ ${ }^{2,3}$ FKIP Universitas Mulawarman \\ ${ }_{1,}^{*}$ Correspondence email: lindaapriati171717@gmail.com \\ ${ }^{2}$ Email: widyatmike@fkip.unmul.ac.id \\ ${ }^{3}$ Email: milyas1010@gmail.com
}

\begin{abstract}
This study aims to develop thematic teaching materials based on interactive multimedia to improve students' listening skills. This study used the research and development model of Borg and Gall (1983). The multimedia-based thematic teaching materials developed were validated by linguists, media experts and graphic experts. The stages of testing teaching materials consist of small group trials and field trials. The validation of material experts was $87.5 \%$; the results of the validation of linguists were $82.5 \%$; the results of the validation of graphic experts were $87.5 \%$. Based on data and student response questionnaires, learning multimedia-based teaching materials can attract students' interest. Student learning outcomes show a positive status. Thus, the product that can be developed is useful in the learning of fourth-grade elementary school students.

Keywords: development, teaching materials, listening skills, interactive multimedia, thematic
\end{abstract}

Abstrak: Penelitian ini bertujuan untuk mengembangkan bahan ajar tematik berbasis multimedia interaktif guna meningkatkan kemampuan menyimak siswa. Penelitian ini menggunakan model penelitian dan pengembangan Borg \& Gall. Bahan ajar tematik berbasis multimedia yang dikembangkan divalidasi oleh ahli bahasa, ahli materi/isi, ahli media dan ahli grafika. Tahapan uji coba bahan ajar terdiri atas uji coba kelompok kecil, dan uji lapangan . Hasil validasi ahli materi sebesar $87,5 \%$, hasil validasi ahli bahasa sebesar $82,5 \%$, hasil validasi ahli media sebesar $88 \%$, hasil validasi ahli grafika sebesar $87,5 \%$. Berdasarkan data dan angket respons siswa, pembelajaran bahan ajar tematik berbasis multimedia dapat menarik minat siswa. Hasil belajar siswa menunjukkan perkembangan positif. Dengan demikian produk yang dikembangkan dinilai efektif dalam pembelajaran siswa kelas IV SD.

Kata kunci: pengembangan, bahan ajar, menyimak, multimedia interaktif, tematik

To cite this article:

Apriati, L., Mulawarman, W. G., Ilyas, M. (2021). Pengembangan Bahan Ajar Menyimak Berbasis Multimedia Interaktif pada Pelajaran Tematik dengan Tema "Indahnya Kebersamaan" untuk Siswa Kelas IV Sekolah Dasar. Diglosia: Jurnal Kajian Bahasa, Sastra, dan Pengajarannya, 4(1), 13-22. https://doi.org/10.30872/diglosia.v4i1.73 


\section{A. PENDAHULUAN}

Dalam era perkembangan iptek yang begitu pesat, profesionalisme tidak cukup hanya dengan kemampuan membelajarkan siswa, tetapi juga harus mampu mengelola informasi dan lingkungan untuk memfasilitasi kegiatan belajar siswa. Namun, Setiap guru mempunyai keterbatasan dalam menyajikan materi pelajaran kepada para siswanya karena berbagai sebab, seperti: konsep yang abstrak, objek yang berbahaya, objek yang tidak terlihat secara kasat mata, dan biaya yang sangat mahal. Berbagai keterbatasan tersebut dapat diatasi antara lain dengan pemanfaatan teknologi informasi dan komunikasi (TIK) dalam rangka untuk mencapai tujuan pembelajaran. Media pembelajaran sangat penting untuk merangsang pikiran, perhatian dan juga minat belajar siswa, untuk itu perlu diperhatikan berbagai hal dalam pemilihan media, antara lain: (a) pemilihan media yang tepat dapat menarik perhatian siswa dan memberikan kejelasan obyek yang diamati, dan (b) bahan pembelajaran yang diajarkan di kelas disesuaikan dengan kemampuan dan pengalaman siswa. Dalam proses pembelajaran, media pengajaran merupakan wahana penyampaian informasi atau pesan pembelajaran yang sangat penting bagi siswa. Pembelajaran melalui penggunaan media, perlahan-lahan mampu menggeser sistem pembelajaran tradisional yang hanya menggunakan buku-buku teks (Dimyati \& Mudjiono, 2006). Guru tidak lagi sebagai satu-satunya sumber belajar bagi siswa. Dengan adanya media, siswa dapat belajar di mana saja, kapan saja dan dengan apa saja. Dengan adanya media pada proses belajar mengajar, diharapkan dapat membantu guru dalam meningkatkan prestasi belajar siswa. Oleh karena itu guru hendaknya menghadirkan media dalam setiap proses pembelajaran demi tercapainya tujuan pembelajaran.

Adapun manfaat penggunaan media multimedia interaktif, yaitu: (a) pembelajaran lebih menarik dan komunikatif; (b) pendidik akan selalu dituntut untuk kreatif inovatif dalam mencari terobosan pembelajaran; (c) dapat menggabungkan antara teks, gambar, audio, musik, animasi gambar atau video dalam satu kesatuan yang saling mendukung guna tercapainya tujuan pembelajaran; (d) memberikan motivasi kepada siswa selama proses belajar mengajar sehingga memperoleh tujuan pembelajaran yang diinginkan; (e) mampu memvisualisasikan materi yang selama ini sulit untuk diterangkan hanya sekedar dengan penjelasan atau alat peraga yang konvensional; dan (f) melatih siswa agar lebih mandiri dalam mendapatkan ilmu pengetahuan. Munir (2012) juga mengatakan pembelajaran harus didukung oleh multimedia interaktif dengan beberapa alasan yang menjadi penguat, antara lain: (a) pesan yang disampaikan dalam materi lebih terasa nyata; (b) merangsang berbagai indera sehingga terjadi interaksi antar indera; (c) visualisasi dalam bentuk teks, gambar, audio, video maupun animasi akan lebih dapat diingat dan ditangkap oleh peserta didik; (d) proses pembelajaran lebih mobile jadi lebih praktis dan terkendali; dan (e) menghemat waktu, biaya dan energi.

Pembelajaran tematik dapat diartikan suatu kegiatan pembelajaran dengan mengintegrasikan materi beberapa mata pelajaran dalam satu tema/topik pembahasan. Pembelajaran tematik merupakan suatu usaha untuk mengintegrasikan pengetahuan, keterampilan, nilai atau sikap pembelajaran, serta pemikiran yang kreatif dengan menggunakan tema (Iskandar, Sabri, \& Abdussamad, 2015; Sutirjo \& Mamik, 2005). Pembelajaran tematik merupakan salah satu model dalam pembelajaran terpadu (integrated instruction) yang merupakan suatu sistem 
pembelajaran yang memungkinkan siswa, baik secara individual maupun kelompok, aktif menggali dan merumuskan konsep serta prinsip-prinsip keilmuan secara holistik, bermakna, dan autentik. Pembelajaran tematik berorientasi pada praktik pembelajaran yang sesuai dengan kebutuhan dan perkembangan siswa.

Salah satu faktor yang berpengaruh dalam pembelajaran adalah bahan ajar (Pratama et al., 2020). Penggunaan bahan ajar pada pembelajaran menyimak yang baik dan menarik, sangat berpengaruh pada proses dan hasil belajar siswa. Pengembangan bahan ajar menyimak harus disesuaikan dengan tingkat berpikir siswa. Materi simakan tidak terlalu panjang agar siswa lebih fokus dan mudah mengingat apa yang disimak. Selain itu materi simakan harus disesuaikan dengan karakteristik siswa, mudah dipahami oleh semua siswa, dan memanfaatkan teknologi yang ada sehingga dapat lebih mudah digunakan dan lebih menarik perhatian siswa. Bahan ajar merupakan seperangkat informasi yang harus diserap peserta didik melalui pembelajaran yang menyenangkan. Hal ini menunjukkan bahwa dalam penyusunan bahan ajar diharapkan siswa benar-benar merasakan manfaat bahan ajar atau materi itu setelah ia mempelajarinya (Nurhana et al., 2020). Bahan ajar merupakan sumber belajar berupa visual maupun audiovisual yang dapat digunakan sebagai saluran alternatif pada komunikasi di dalam proses pembelajaran.

Menyimak adalah mendengarkan atau memperhatikan baik-baik apa yang diucapkan atau dibaca orang. Menyimak adalah dasar untuk menguasai suatu bahasa. Apabila kemampuan seseorang dalam mendengarkan kurang, dapat dipastikan dia tidak dapat mengungkapkan topik yang didengar dengan baik. Menyimak adalah suatu proses kegiatan mendengarkan lambang-lambang lisan dengan penuh perhatian, pemahaman, apresiasi, serta interpretasi untuk memperoleh informasi, menangkap isi, serta memahami makna komunikasi yang tidak disampaikan oleh sang pembicara melalui ujaran atau bahasa lisan (Tarigan, 2006).

Faktor penentu keberhasilan menyimak bergantung pada beberapa faktor yaitu: pembicara, pembicaraan, situasi, dan penyimak. Pertama, pembicara adalah orang yang menyampaikan pesan, ide, informasi kepada para pendengar melalui bahasa lisan. Pembicara harus mempunyai tuntutan yaitu penguasaan materi, berbahasa, percaya diri, berbicara sistematis, gaya bicara menarik, dan kontak dengan pendengar. Kedua, pembicaraan adalah materi, isi, pesan, atau informasi yang hendak disampaikan oleh seseorang pembicara pada pendengarnya. Pembicara yang baik harus memenuhi syarat-syarat yaitu aktual, bermakna, dalam minat pendengar, sistematis, dan seimbang. Ketiga, situasi sangat berpengaruh dan menentukan keefektifan menyimak. Situasi dalam menyimak diartikan sebagai segala sesuatu yang menyertai peristiwa menyimak di luar pembicara, pembicaraan, dan menyimak. Hal-hal yang harus diperhatikan dalam proses menyimak antara lain ruangan, waktu, tenang, dan peralatan. Keempat, penyimak adalah orang yang mendengarkan dan memahami isi bahan simakan yang disampaikan oleh pembicara dalam suatu peristiwa menyimak. Penyimak merupakan faktor terpenting dan yang paling menentukan keefektifan dalam peristiwa menyimak. Hal-hal yang perlu diperhatikan agar kegiatan menyimak bisa tercapai adalah kondisi, konsentrasi, bertujuan, berminat, mempunyai kemampuan linguistik dan nonlinguistik, dan pengalaman serta pengetahuan yang luas (Tarigan, 1991).

Proporsi kegiatan menyimak dalam proses pembelajaran bahasa lebih besar jika dibandingkan dengan kegiatan berbahasa lainnya (Septyanti \& Kurniama, 2020). 
Dalam kegiatan pembelajaran bahasa serta dalam kehidupan sehari-hari menyimak memegang peran yang dominan sehingga perlu diajarkan dan dilatih dengan baik dan kontinu (Niarti, Ruminto, \& Haenilah, 2017). Peserta didik yang memiliki kemampuan menyimak yang baik akan mudah memahami apa yang didengarnya dan biasanya akan bisa menyerap lebih banyak informasi yang disimaknya bila dibandingkan dengan peserta didik yang memiliki kemampuan menyimak rendah (Marlianti, Marli, \& Halidjah, 2018).

Tidak dapat dipungkiri bahwa keterampilan menyimak masih mengalami beberapa kendala, di antaranya adalah (a) teori, prinsip, dan generalisasi mengenai menyimak belum banyak diungkapkan, (b) pemahaman terhadap apa dan bagaimana menyimak itu masih minim, (c) buku teks dan buku pegangan guru dalam masyarakat masih langka, (d) bahan pengajaran menyimak masih kurang, dan (e) jumlah murid per kelas terlalu besar (Niarti et al., 2017)

Multimedia yaitu penyampaian informasi menggunakan beberapa gabungan beberapa media yang berupa teks, grafik, suara, dan video (Widodo, 2008). multimedia merujuk kepada berbagai kombinasi dari dua atau lebih format media yang terintegrasi ke dalam bentuk informasi atau program instruksi. Multimedia interaktif adalah suatu multimedia yang dilengkapi dengan alat pengontrol yang dapat dioperasikan oleh pengguna sehingga pengguna dapat memilih apa yang dikehendaki untuk proses selanjutnya. Karakteristik terpenting dari multimedia interaktif adalah siswa tidak hanya memperhatikan media atau objek saja, melainkan juga dituntut untuk berinteraksi selama mengikuti pembelajaran (Andajani, 2016; Heinich, Molenda, \& Russell, 1992).

Berdasarkan hasil observasi yang dilakukan penulis tanggal 20 Juli 2019, pada pembelajaran tematik tema "Indahnya Kebersamaan" di kelas IV SD Al Azhar 47 Samarinda, pembelajaran menyimak masih mengalami beberapa kendala salah satunya motivasi belajar siswa yang masih rendah. Pernyataan ini dibenarkan oleh Riduwan (2019) yang mengatakan bahwa motivasi belajar adalah keseluruhan daya penggerak dalam diri siswa yang menimbulkan kegiatan belajar, yang menjamin kelangsungan dari kegiatan belajar dan memberi arah pada kegiatan belajar, sehingga tujuan yang dikehendaki oleh subjek belajar itu dapat tercapai. Lebih lanjut Riduwan mengatakan motivasi merupakan suatu daya atau kekuatan yang timbul dari dalam diri siswa untuk memberikan kesiapan agar tujuan yang telah ditetapkan tercapai. Beberapa hal yang mempengaruhi rendahnya motivasi belajar pada siswa yaitu penyajian materi pembelajaran yang masih fokus pada guru sehingga menyebabkan pembelajaran searah dan siswa kurang mampu mengasah kemampuan pada dirinya.

Anak-anak yang masih duduk di Sekolah Dasar sangat aktif bermain. Apabila guru hanya mengandalkan media buku dalam pembelajaran maka anak-anak akan lebih cepat merasa bosan ketika proses belajar. Dalam kasus seperti ini, menggunakan multimedia adalah cara yang cukup ampuh dalam menghilangkan kejenuhan peserta didik. Pembelajaran dengan multimedia lebih menarik minat peserta didik ketika belajar dikarenakan materi yang disampaikan lebih nyata dalam kehidupan sehari-hari. Penggunaan pembelajaran multimedia ini juga menjadi salah satu alternatif bagi guru untuk dapat mencapai kompetensi pembelajaran tematik tema "Indahnya Kebersamaan" serta dapat meningkatkan kualitas peserta didik.

Berdasarkan pentingnya upaya peningkatan kualitas proses pembelajaran maka sangat diperlukan adanya pengembangan suatu media pembelajaran yang bersifat 
interaktif berupa bahan ajar berbasis multimedia interaktif. Multimedia pembelajaran yang berbasis komputer dinilai lebih interaktif karena komputer dinilai mampu melengkapi para siswa dengan model pembelajaran, latihan, alat referensi dan tes.

\section{B. METODE}

Penelitian ini dilaksanakan di Sekolah Dasar Islam Al Azhar 47 Samarinda, Kecamatan Sungai Kunjang, Kota Samarinda. Pelaksanaan penelitian pada semester ganjil tahun pelajaran 2019/2020. Responden yang dipilih adalah ahli materi, ahli grafika, ahli bahasa, dan ahli media. Penelitian ini termasuk ke dalam penelitian dan pengembangan $(\mathrm{R} \& \mathrm{D})$. Penelitian pengembangan adalah suatu proses yang yang digunakan dalam mengembangkan dan memvalidasi produk-produk pendidikan, yang tidak hanya bersifat materi seperti buku teks, film pembelajaran dan lain-lain, tetapi juga merupakan prosedur dan proses, seperti metode pengajaran atau metode pengelolaan pembelajaran (Gall, Gall, \& Borg, 2003). Penelitian dan pengembangan pendidikan meliputi beberapa tahapan di mana terdapat suatu produk yang dikembangkan, dites, dan direvisi sesuai hasil tes lapangan. Model pengembangan ini menggunakan 10 tahap yang terdiri atas: (1) tahap penelitian dan pengumpulan informasi awal, (2) tahap perencanaan, (3) tahap pengembangan format produk awal, (4) tahap uji coba awal oleh validasi, (5) tahap revisi produk, (6) tahap uji coba lapangan, (7) tahap revisi produk, (8) tahap uji lapangan, (9) tahap revisi produk akhir, (10) tahap diseminasi dan implementasi (Reza et al., 2020).

Subjek penelitian ini terdiri atas ahli isi (materi), ahli bahasa, ahli media, dan ahli grafika sebagai validator. Selain itu, guru dan siswa kelas IV SD Islam Al Azhar 47 Samarinda sebagai pengguna. Jenis data yang didapat merupakan data kualitatif dan kuantitatif, data yang diperoleh dari angket. Data kualitatif didapatkan dari hasil penilaian, masukan, tanggapan, kritikan dan saran perbaikan melalui instrumen yang telah disediakan. Untuk data kuantitatif data yang diperoleh melalui perolehan belajar setelah pembelajaran menyimak berbasis multimedia interaktif dengan menggunakan video. Data yang dikumpulkan antara lain: (a) penilaian dari ahli materi pembelajaran mengenai kualitas produk yang dikembangkan, meliputi segi pembelajaran, kurikulum, isi materi, interaksi, bahasa dan soal evaluasi; (b) penilaian dari ahli media pembelajaran mengenai kualitas produk yang dikembangkan, meliputi segi pewarnaan, tampilan layar, dan suara; (c) penilaian peserta didik mengenai kualitas produk yang dikembangkan, meliputi: pengoperasian program dan reaksi pengguna; dan (d) hasil pretes dan postes peserta didik.

Pengumpulan data dilakukan melalui observasi di sekolah, wawancara guru dan siswa, analisis buku siswa dan buku guru. Sementara itu, data penelitian diperoleh pada saat validasi bahan ajar dan uji coba produk. Validasi bahan ajar dilakukan oleh ahli materi, ahli bahasa, ahli grafika, dan ahli media. Uji coba produk dilakukan sebanyak dua tahap, pertama uji coba kelompok kecil terdiri atas sepuluh orang siswa dan satu orang guru kelas IV. Uji kelas besar terdiri atas 21 siswa dan satu orang guru. Instrumen penelitian terdiri atas lembar angket validasi ahli materi, lembar angket ahli bahasa, lembar angket ahli grafika dan lembar angket ahli media, angket respons siswa, angket respons guru, dan hasil belajar. 


\section{PEMBAHASAN}

Angket yang dianalisis pada penelitian terdiri atas angket validasi ahli dan data uji coba. Validasi dilakukan empat orang validasi yaitu ahli media, ahli grafika, ahli materi dan ahli bahasa yang bertujuan untuk memvalidasi tingkat kevalidan bahan ajar tematik yang dikembangkan dan media pembelajaran yang digunakan. Uji coba dilakukan oleh guru dan siswa kelas IV Sekolah Dasar Islam Al Azhar 47 Samarinda yang bertujuan mengetahui tingkat kemenarikan bahan ajar dan media yang digunakan dalam proses pembelajaran siswa. Uji coba produk dilaksanakan melalui tiga tahap yaitu uji coba kelas kecil, uji coba kelas besar, dan uji coba lapangan. Analisis data dalam penelitian ini menggunakan analisis deskriptif kualitatif dan analisis deskriptif kuantitatif. Data berupa saran dan masukan dianalisis menggunakan deskriptif kualitatif sedangkan data berupa skor dan nilai dianalisis menggunakan analisis deskriptif kuantitatif.

Produk bahan ajar tematik yang sudah dikembangkan diuji kelayakannya oleh validasi ahli media, ahli grafika, ahli materi dan ahli bahasa. Berdasarkan validasi dari ahli media, ahli grafika, ahli materi dan ahli bahasa dinyatakan sudah layak dan digunakan setelah melakukan beberapa revisi berdasarkan saran dan masukan dari para validator ahli. Kelayakan bahan ajar mencapai kriteria layak. Bahan ajar yang telah di revisi dapat digunakan untuk uji coba produk. Perolehan dari validasi ahli dijelaskan pada Tabel 1 . Berdasarkan Tabel 1 bahwa rata-rata kevalidan buku siswa dan guru sebesar $84.25 \%$ dengan kriteria layak, rata-rata kevalidan media pembelajaran sebesar $83 \%$ dengan kriteria sangat layak sedangkan rata-rata ahli grafika sebesar $80 \%$. Saran secara umum bahwa buku siswa dan guru serta media pembelajaran berbasis multimedia layak digunakan untuk uji coba produk setelah melakukan revisi sesuai catatan pada lembar validasi ahli.

Uji coba kelompok kelas kecil dilakukan terhadap sepuluh orang siswa kelas IVB Sekolah Dasar Islam Al Azhar 47 Samarinda. Uji coba kelompok kelas kecil bertujuan mengetahui kepraktisan bahan ajar tematik yang dibuat. Data dikumpulkan menggunakan angket respons guru dan respons siswa. Data hasil uji coba kelompok kelas kecil disajikan pada Tabel 2. Berdasarkan Tabel 2 diketahui bahwa rata-rata kepraktisan buku guru sebesar 93\% dengan kriteria sangat layak. Sedangkan rata-rata kepraktisan buku siswa sebesar 76\% dengan kriteria layak. Saran dan komentar saat uji coba kelompok kelas kecil dijadikan sebagai dasar revisi bahan ajar tematik yang diujikan pada uji coba lapangan.

Uji coba kelompok kelas besar dilakukan terhadap 21 orang siswa kelas IVB Sekolah Dasar Islam Al Azhar 47 Samarinda. Uji coba kelompok kelas besar bertujuan mengetahui kepraktisan bahan ajar tematik yang dibuat. Data dikumpulkan menggunakan angket respons guru dan respons siswa. Data hasil uji coba kelompok kelas besar disajikan pada Tabel 3. Berdasarkan Tabel 3 diketahui bahwa rata-rata kepraktisan buku guru sebesar 93\% dengan kriteria sangat layak. Sedangkan rata-rata kepraktisan buku siswa sebesar 85,6\% dengan kriteria sangat layak. Saran dan komentar saat uji coba kelompok kelas kecil dijadikan sebagai dasar revisi bahan ajar tematik yang diujikan pada uji coba lapangan.

Uji coba lapangan dilakukan terhadap satu orang guru dan 21 orang siswa kelas IVB Sekolah Dasar Islam Al Azhar 47 Samarinda. Uji coba lapangan bertujuan untuk mengetahui kepraktisan bahan ajar tematik yang dikembangkan. Uji coba lapangan dilaksanakan selama satu minggu. Data uji coba lapangan diperoleh dari 
angket respons guru dan respons siswa. Data kepraktisan dari uji coba lapangan disajikan pada Tabel 4. Berdasarkan Tabel 4 diketahui bahwa rata-rata kepraktisan buku guru sebesar 93\% dengan kriteria sangat layak sedangkan rata-rata kepraktisan buku siswa sebesar 83\% dengan kriteria sangat layak. Rata-rata kepraktisan bahan ajar tematik yang diperoleh pada saat uji coba kelompok kelas kecil, uji coba kelas besar dan uji coba lapangan disajikan pada Tabel 4.

Produk yang dikembangkan dalam penelitian dan pengembangan ini adalah buku guru dan buku siswa kelas IV Sekolah Dasar dengan tema "Indahnya Kebersamaan" serta pembelajaran berbasis multimedia. Tema "Indahnya Kebersamaan" serta pembelajaran berbasis multimedia diajarkan pada semester ganjil di kelas IV Sekolah Dasar yang menerapkan Kurikulum 2013. Tema "Indahnya Kebersamaan" dipilih karena peneliti ingin memperkenalkan keberagaman yang ada di Indonesia khususnya Kalimantan Timur. Sebagaimana diketahui bahwa Kalimantan Timur memiliki ragam budaya mulai dari adat, bahasa dan tradisi. Data yang dihasilkan pada penelitian dan pengembangan ini adalah data kelayakan bahan ajar tematik. Data kelayakan diperoleh berdasarkan hasil validasi ahli materi, ahli bahasa, ahli media, dan ahli grafika serta angket respons siswa dan angket respons guru. Uji coba dalam penelitian ini dilaksanakan melalui tiga tahap yaitu tahap uji coba kelas kecil, uji coba kelas besar dan uji coba lapangan. Uji coba kelas kecil berjumlah satu orang guru dan sepuluh orang siswa. Uji coba kelas besar berjumlah satu orang guru dan 21 orang siswa. Uji coba lapangan berjumlah satu orang guru dan 21 orang siswa kelas IV Sekolah Dasar. Data yang terkumpul untuk mengetahui tingkat kelayakan bahan ajar yang dikembangkan. Sebelum uji coba, produk bahan ajar tematik tema "Indahnya Kebersamaan" yang sudah disusun, terlebih dahulu divalidasi oleh ahli materi, ahli bahasa, ahli media dan ahli grafika. Ahli materi dan ahli bahasa memberikan penilaian, saran dan masukan mengenai isi materi dan kebahasaan pada buku yang dikembangkan. Ahli media dan grafika memberikan penilaian mengenai desain sampul buku dan media pembelajaran yang dikembangkan. Tujuan dari validasi ahli adalah untuk mengetahui tingkat kelayakan bahan ajar tematik yang dibuat. Hasil validasi ahli materi menunjukkan kevalidan sebesar $87,5 \%$ dengan kategori sangat layak. Hasil validasi ahli bahasa menunjukkan kevalidan sebesar $82,5 \%$ dengan kategori baik. Hasil validasi ahli media menunjukkan kevalidan sebesar $83 \%$ dengan kategori baik. Hasil validasi uji coba menunjukkan kevalidan sebesar 85,75\%.

Tabel 1. Rekapitulasi Validasi Buku dan Media Pembelajaran

\begin{tabular}{|c|c|c|}
\hline \multirow{2}{*}{ Validator } & \multicolumn{2}{|c|}{ Persentase } \\
\hline & Buku Siswa dan Guru & Media Pembelajaran \\
\hline Ahli materi & $86 \%$ & - \\
\hline Ahli bahasa & $82,5 \%$ & - \\
\hline Ahli media & - & $83 \%$ \\
\hline Ahli grafika & - & $80 \%$ \\
\hline Rata-rata & $84,25 \%$ & $81.5 \%$ \\
\hline Kategori & Sangat layak & layak \\
\hline
\end{tabular}


Tabel 2. Data Uji Coba Kelompok Kelas Kecil

\begin{tabular}{lccc}
\hline & \multirow{2}{*}{ Responden } & \multicolumn{2}{c}{ Persentase } \\
\cline { 2 - 3 } & Buku Siswa & Buku Guru \\
\hline Guru & - & $93 \%$ \\
Siswa & $76 \%$ & - \\
\hline Rata-rata & $76 \%$ & $93 \%$ \\
\hline Kategori & Layak & Sangat layak \\
\hline
\end{tabular}

Tabel 3. Data Uji Coba Kelompok Kelas Besar

\begin{tabular}{lccc}
\hline & Responden & \multicolumn{2}{c}{ Persentase } \\
\cline { 2 - 3 } & Buku Siswa & Buku Guru \\
\hline Guru & - & $93 \%$ \\
Siswa & $85,6 \%$ & - \\
\hline Rata-rata & $85,6 \%$ & $93 \%$ \\
\hline Kategori & Sangat layak & Sangat layak \\
\hline
\end{tabular}

Tabel 4. Data Uji Coba Lapangan

\begin{tabular}{lcc}
\hline & \multirow{2}{*}{ Responden } & \multicolumn{2}{c}{ Persentase } \\
\cline { 2 - 3 } & Buku Siswa & Buku Guru \\
\hline Guru & - & $93 \%$ \\
Siswa & $83 \%$ & - \\
\hline Rata-rata & $83 \%$ & $93 \%$ \\
\hline Kategori & Sangat layak & Sangat layak \\
\hline
\end{tabular}

\section{PENUTUP}

Hasil pengembangan pembelajaran terkait bahan ajar menyimak berbasis multimedia interaktif pada pelajaran Tematik dengan tema "Indahnya Kebersamaan" untuk siswa kelas IV Sekolah Dasar dilakukan melalui uji validasi dan uji para ahli serta uji coba produk. Kevalidan pembelajaran dilihat dari isi/materi, penyajian bahasa, penyajian grafik dan penyajian media pembelajarannya. Dengan kategori layak. Proses pengembangan bahan ajar menyimak berbasis multimedia interaktif pada pelajaran Tematik dengan tema "Indahnya Kebersamaan" untuk siswa kelas IV Sekolah Dasar dikembangkan dengan model pengembangan yang mengacu pada rancangan penelitian dan pengembangan menurut Borg \& Gall. Dengan perubahan dan modifikasi peneliti seperlunya sesuai kebutuhan peneliti. Bahan ajar yang dikembangkan berupa buku pegangan siswa dengan materi pengembangan bahan ajar menyimak berbasis multimedia interaktif pada pelajaran tematik dengan tema "Indahnya Kebersamaan" untuk siswa kelas IV sekolah dasar. Produk yang dikembangkan juga telah memenuhi komponen sebagai bahan ajar yang baik untuk digunakan dikarenakan bahan ajar telah sesuai dengan KI-KD, sesuai dengan keadaan siswa, Bahasa yang digunakan mudah, dan juga memiliki kesesuaian warna, ukuran dan jenis huruf menarik yang akan memotivasi siswa agar lebih bersemangat belajar sehingga hasil belajar juga menjadi meningkat. Pengembangan bahan ajar menyimak berbasis multimedia interaktif pada siswa kelas IV SD memiliki keefektifan sangat baik. Hal ini dapat dilihat dari hasil evaluasi siswa, 81\% 
siswa dapat mencapai Kriteria Ketuntasan Minimal (KKM) yang ditentukan oleh pihak sekolah.

\section{DAFTAR PUSTAKA}

Andajani, S. J. (2016). Multimedia Interactive Based Orientation and Mobility Based on Concept Mastery Embedding the School Environment on Blind Student. Proceedings of International Research Clinic \& Scientific Publications of Educational Technology, 82-101. Retrieved from https://journal.unesa.ac.id/index.php/jtp/article/view/1148

Dimyati, \& Mudjiono. (2006). Belajar dan Pembelajaran. Jakarta: Rineka Cipta.

Gall, M. D., Gall, J. P., \& Borg, W. R. (2003). Educational Research: An Introduction (7th ed.). London: Longman.

Heinich, R. H. R., Molenda, M., \& Russell, J. D. (1992). Instuctional Media and the New Technologies of Instruction (4th ed.). London: Macmillan Coll Div.

Iskandar, Sabri, T., \& Abdussamad. (2015). Peningkatan Aktivitas Peserta Didik dalam Pembelajaran Tematik Menggunakan Pendekatan Saintifik SDN 04 Benua Kayong. Jurnal Pendidikan Dan Pembelajaran Khatulistiwa, 4(1). Retrieved from https://jurnal.untan.ac.id/index.php/jpdpb/article/view/8595

Marlianti, E., Marli, S., \& Halidjah, S. (2018). Peningkatan Keterampilan Menyimak Peserta Didik Menggunakan Media Audio Cerita Anak Kelas V SD. Jurnal Pendidikan dan Pembelajaran Khatulistiwa, 7(7). Retrieved from https://jurnal.untan.ac.id/index.php/jpdpb/article/view/26827

Marta, L. N. P. M., Mursalim, \& Suhatmady, B. (2020). Pengembangan Bahan Ajar Menulis Berita pada Siswa SMP Kelas VIII. Diglosia: Jurnal Kajian Bahasa, Sastra, dan Pengajarannya, 3(3), 243-252. https://doi.org/10.30872/diglosia.v3i3.60

Munir. (2012). Multimedia: Konsep dan Aplikasi dalam Pendidikan. Bandung: Alfabeta. Niarti, N., Ruminto, N. E., \& Haenilah, E. Y. (2017). Pengembangan Bahan Ajar Berbasis Multimedia Interaktif pada Materi Menyimak untuk Siswa Kelas VI SD. Jurnal Pedagogi, 5(1), 1-17. Retrieved from http://jurnal.fkip.unila.ac.id/index.php/pedagogi/article/view/11736/0

Nurhana, Siddik, M., \& Ridhani, A. (2020). Pengembangan Bahan Ajar Menulis Cerpen dengan Teknik Parafrase pada Peserta Didik Kelas XI MAN 2 Samarinda. Diglosia: Jurnal Kajian Bahasa, Sastra, dan Pengajarannya, 3(2), 211220. https://doi.org/10.30872/diglosia.v3i2.63

Pratama, G. Y., Haruna, J., \& Siddik, M. (2020). Pengembangan Bahan Ajar Menulis Puisi dengan Perpaduan Model Demonstrasi dan Teknik Beriur Kata Kelas VIII SMP. Diglosia: Jurnal Kajian Bahasa, Sastra, dan Pengajarannya, 3(2), 149-162. https://doi.org/10.30872/diglosia.v3i2.58

Reza, M., Hudiyono, Y., \& Yahya, M. (2020). Pengembangan Bahan Ajar Menulis Fabel dengan Model Sinektik pada Peserta Didik Kelas VII SMP Muhammadiyah 1 Balikpapan. Diglosia: Jurnal Kajian Bahasa, Sastra, dan Pengajarannya, 3(2), 179-188. https://doi.org/10.30872/diglosia.v3i2.45

Riduwan. (2019). Belajar Mudah Penelitian untuk Guru-Karyawan dan Peneliti Pemula. Bandung: Alfabeta.

Septyanti, E., \& Kurniaman, O. (2020). Studi Eksploratif Kebutuhan Pembelajaran Daring untuk Mata Kuliah Menyimak pada Masa Pandemi Covid-19. Diglosia: 
Jurnal Kajian Bahasa, Sastra, dan Pengajarannya, 3(4), 365-372. Retrieved from http://diglosiaunmul.com/index.php/diglosia/article/view/100

Sutirjo, \& Mamik, S. I. (2005). Tematik: Pembelajaran Efektif dalam Kurikulum 2004. Malang: Bayumedia Publishing.

Tarigan, D. (1991). Materi Pokok Pendidikan Bahasa Indonesia I. Jakarta: Depdikbud. Tarigan, H. G. (2006). Menulis Sebagai Suatu Keterampilan Berbahasa. Bandung: Angkasa.

Widodo, C. S. (2008). Panduan Menyusun Bahan Ajar Berbasis Kompetensi. Jakarta: Elex Media Komputindo. 